\title{
PENGARUH LEVERAGE, FINANCIALDISTRESS DAN LIQUIDITY SEBAGAI PENGAMBILAN KEPUTUSAN HEDGING (Studi Kasus pada Perusahaan yang Terdaftar pada Bursa Jakarta Islamic Index Periode 2011-2015)
}

\author{
Al Fatimia \\ Muhammad Sulhan \\ Universitas Islam Negeri (UIN) Maulana Malik Ibrahim Malang \\ Email: fatimiaal@gmail.com \\ Sulhan100@gmail.com
}

\begin{abstract}
Hedging is one alternative risk management to protect the assets of the company resulting from the foreign exchange risk. Hedging by using derivative instrumentis common ways that is used by the company. This study aimed to determine the effect of leverage, and liquidity of financial distress, both simultaneously and partially to the company's decision to do hedging. The population in this study was a company in Jakarta Islamic Index on the observation period of 2011-2015. The sampling technique used in this research was purposive sampling method in order to obtain a sample of seven companies. The techniques in this study used multiple regression analysis software of SPSS version 16. The results of this study that of the four variables used, there was one variable that affected the company to be used as a hedging decision making. Variable that affected the hedging activities was the current ratio, because if the value of the current ratio was high then indicated that the liquid assets that was managed by the company was also high, so it needed to implement a policy of hedging, quick ratio was getting the negative and significant, which meant that if the value of the variable quick ratio was low, then the company pushed for hedging, debt to equity ratio had no significant effect on hedging, this was because the company was using the rupiah currency to do debt, financial distress had no significant because the company was not experiencing the financial difficulties.
\end{abstract}

Keywords: decision hedging, leverage, financial distress and liquidity

Pada kondisi ketidakstabilan ekonomi global saat ini, dimana ditandai dengan terus meningkatnya total utang luar negeri yang terus meningkat pada tiap tahunnya memberikan dampak yang tidak menguntungkan (upside risk) terhadap perekonomian. Pada akhir 2015, jumlah total utang luar negeri tercatat sebesar 223,2 miliar USD dimana dengan rasio utang terhadap produk domestik bruto (PDB) sebesar 27 persen (www.kompas.com). Jumlah utang luar negeri yang sangat besar dimiliki oleh sektor perusahaan non keuangan, dimana perusahaan tersebut berpotensi memiliki risiko ketidaksesuaian nilai tukar (currency mismatch) sebagai akibat dari fluktuasi pergerakan nilai tukar khususnya pengaruh dari depresiasi nilai tukar (Indawan, dkk., 2012). Berikut merupakan gambar grafik hutang luar negeri yang dilakukan oleh perusahaan non keuangan dan lembaga keuangan.

Dari gambar 1 hutang luar negeri yang dilakukan oleh perusahaan non keuangan maupun lembaga keuangan dari amatan tahun 2010 sampai 2014

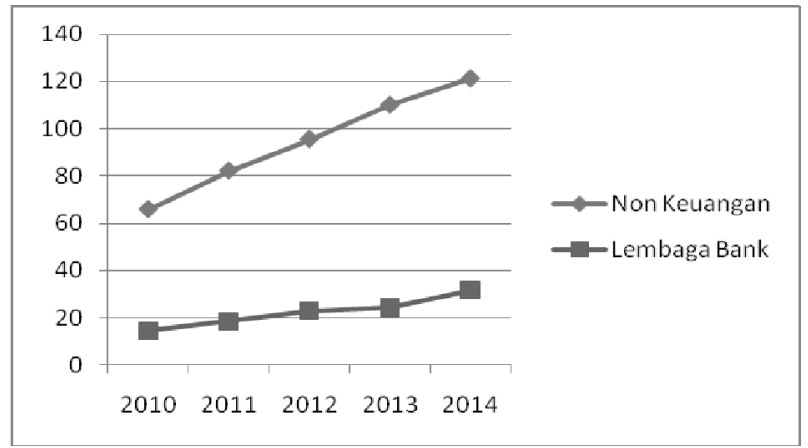

Gambar 1. HutangLuar Negeri Perusahaan Non Keuangan dan Lembaga Keuangan Periode Tahun 2010 2014

Sumber: BPS 2016 (data diolah)

mengalami tren yang naik, sehingga dapat disimpulkan bahwasanya hutang luar negeri yang dilakukan perusahaan baik itu lembaga keuangan dan lembaga bank mengalami kenaikan tiap tahunnya. Akan tetapi perlu digaris bawahi juga menurut data pada gambar di 
atas, hutang luar negeri cenderung didominasi oleh perusahaan non keuangan.

Selain itu, perdagangan bebas di era globalisasi saat ini dihadapi dengan semakin meningkatnya persaingan serta gejolak harga pasar yang membuat ketidakpastian atau risiko usaha semakin meningkat dalam mempertahankan usahanya, baik usaha kecil, menengah, dan besar berlomba-lomba untuk mempertahankan usahanya tersebut dengan berbagai cara untuk menyesuaikan dengan risiko-risiko yang terjadi (Putro \& Chabachib, 2012).

Risiko dapat dialami oleh semua perusahaan, terlebih perusahaan yang melakukan perdagangan internasional. Risiko yang dihadapi akan lebih kompleks, dengan demikian, perusahaan perlu melakukan manajemen risiko. Risiko dapat diketahui oleh perusahaan dengan mengukur terlebih dahulu eksposur yang dapat dialami perusahaan. Eksposur valuta asing terjadi dikarenakan adanya penundaan penyelesaian transaksi dalam perdanganan. Eksposur tersebut disebabkan oleh jeda waktu antara saat persetujuan harga dan penyerahan barang, serta harga penyelesaian yang didenominasi dalam mata uang asing (Paranita, 2011). Berikut merupakan grafik perubahan nilai tukar valuta asing khususnya Dollar terhadap Rupiah.

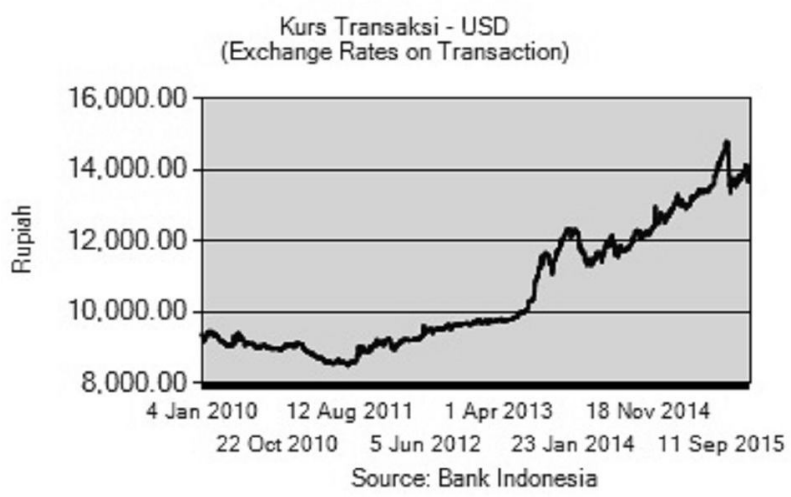

Gambar 2. Pergerakan Nilai Tukar Rupiah terhadap Dollar Amatan Tahun 2010-2014

Dari gambar 2 diatas menunjukkan pergerakan fluktuasi nilai tukar rupiah terhadap Dollar, dimana pada tahun 2010 sampai 2014 jika dilihat dari grafik di atas memiliki tren yang cenderung naik (depresiasi). Dengan demikian apabila perusahaan melakukan perjanjian transaksi pada tahun 2013 dan jatuh tempo pada tahun 2014, maka perusahaan harus membayar lebih kewajibannya, hal ini dikarenakan karena terjadi depresiasi rupiah terhadap Dollar. Namun tidak demikian apabila perusahaan melakukan hedging dengan menggunakan salah satu instrumen derivatif yang dapat meminimalisir risiko atau kerugian.

Strategi hedging yang digunakan oleh perusahaan atas transaksi-transaksi keuangnnya, instrumen derivatif salah satu alternatif dalam pasar modal yang cukup berperan (Jiwandhana \& Triaryati, 2016). Derivatif merupakan instrumen keuangan yang nilainya berasal dari nilai aset lain, kelompok aset, atau variabel ekonomis seperti harga saham, obligasi, harga komoditas, tingkat bunga, atau kurs pertukaran valuta (Subramanyam \& Wild, 2013:356).

Kebijakan perusahaan yang melakukan aktivitas hedging pada dasarnya telah termotivasi oleh keinginan perusahaan untuk memaksimumkan kekayaan pemegang sahamnya (shareholder value maximization), dengan mengurangi biaya transaksi yang berkaitan dengan financial distress. Dimana biaya transaksi adalah biaya yang ditimbulkan oleh aktivitas transaksi multinasional perusahaan yang sangat rentan terhadap fluktuasi valuta asing. Sehingga dapat ditarik kesimpulan bahwa keputusan perusahaan dalam melakukan hedging dapat mengurangi risiko financial distress (Fitriasari, 2011).

Tujuan dari penelitian ini adalah (1) untuk mengetahui pengaruh leverage, financial distress dan liquidity secara simultan terhadap keputusan perusahaan dalam melakukan hedging, (2) untuk mengetahui pengaruh leverage, financial distress dan liquidity secara parsial terhadap keputusan hedging.

\section{RESIKO}

Risiko muncul karena ada kondisi ketidakpastian. Risiko didefinisikan dalam kamus Webster sebagai "suatu halangan, gangguan, eksposur terhadap kerugian atau kecelakaan". Jadi, risiko diartikan sebagai peluang akan terjadinya suatu peristiwa yang tidak diinginkan (Brigham \& Houston, 2007:323). Pengertian risiko juga dapat diartikan sebagai kerugian karena kejadian yang tidak diharapka terjadi (Sunaryo, 2007:11). Menurut Hanafi (2006: 6) salah satu cara untuk mengelompokkan risiko adalah dengan melihat tipe-tipe risiko, dimana tipe-tipe risiko terdiri atas: (1) Risiko Murni, (2) Risiko Spekulatif.

\section{HEDGING}

Menurut Faisal (2001:9) hedging adalah tindakan yang dilakukan oleh perusahaan untuk menghindari/mengurangi risiko kerugian atas valas sebagai akibat dari terjadinya transaksi bisnis. Sedangkan 
Hanafi (2006:261) mendefinikan hedging pada dasarnya mentransfer risiko kepada pihak lain yang lebih bisa mengelola risiko lebih baik melalui transaksi instrumen keuangan.

\section{Leverage}

Rasio leverage merupakan rasio yang menunjukkan beberapa bagian dari keseluruhan modal dan dana yang dibelanjai dengan utang. Di mana alat analisis dapat dihitung dengan menggunakan Dept equity ratio merupakan rasio yang digunakan untuk mengukur kemampuan modal sendiri perusahaan untuk dijadikan jaminan semua hutang perusahaan. Debt equity ratio merupakan perbandingan antara jumlah hutang dengan jumlah modal sendiri. Rasio ini menunjukkan kemampuan koperasi dalam memenuhi keseluruhan hutang dengan menggunakan modal sendiri. Artinya jika sewaktu-waktu dilikuidasi koperasi ini sudah cukup mampu dalam memenuhi kewajiban jangka pendek maupun jangka panjang (Muqorobin \& Nasir, 2009). Secara matematis DER dapat diformulasikan sebagai berikut: (Kasmir, 2010:157).

Debt to Equity Ratio $(D E R)=\frac{\text { Total Hutang }}{\text { Total Ekuitas }}$

\section{Financial Distress}

Financial Distress adalah kondisi di mana perusahaan mengalami kesulitan keuangan dan terancam bangkrut. Pada umumnya, kemungkinan terjadinya financial distress semakin meningkat dengan meningkatnya penggunaan hutang. Logikanya adalah semakin besar penggunaan hutang, semakin besar pula beban biaya bunga, semakin besar probabilita bahwa penurunan penghasilan akan menyebabkan financial distress (Atmaja, 2008:258). Di mana financial distress dapat dirumuskan sebagai berikut:

$$
\begin{array}{r}
Z=\frac{\text { Working Capital }}{\text { Total Assets }}+\frac{\text { Retairned Earning }}{\text { Total Assets }}+\frac{\text { EAT }}{\text { Total Assets }} \\
+\frac{\text { Market Value of Equity }}{\text { Book value of Total Debt }}+\frac{\text { Total Revenue }}{\text { Total Assets }}
\end{array}
$$

\section{Liquidity}

Konsep likuiditas dapat diartikan sebagai kemampuan perusahaan dalam melunasi sejumlah utang jangka pendek, umumnya kurang dari satu tahun. Dimensi konsep likuiditas mencakup current ratio dan quick ratio. Current ratio (rasio lancar) adalah perbandingan antara aktiva lancar dengan hutang lancar. Perhitungan rasio ini akan menunjukkan kemampuan perusahaan dalam memenuhi hutang jangka pendek dengan menggunakan aktiva lancar.
Sedangkan quick ratio (rasio cepat) merupakan perbandingan antara aktiva lancar setelah dikurangi persediaan dengan hutang lancar (Muqorobin \& Nasir, 2009). Dimana rumus current ratio dan quick ratio adalah sebagai berikut:

$$
\begin{aligned}
& \text { Current Rasio }=\frac{\text { Aktiva Lancar }}{\text { Pasiva Lancar }} \\
& \text { Quick Ratio }=\frac{\text { Aktiva Lancar }- \text { Persediaan }}{\text { Pasiva Lancar }}
\end{aligned}
$$

\section{KERANGKA KONSEPTUAL}

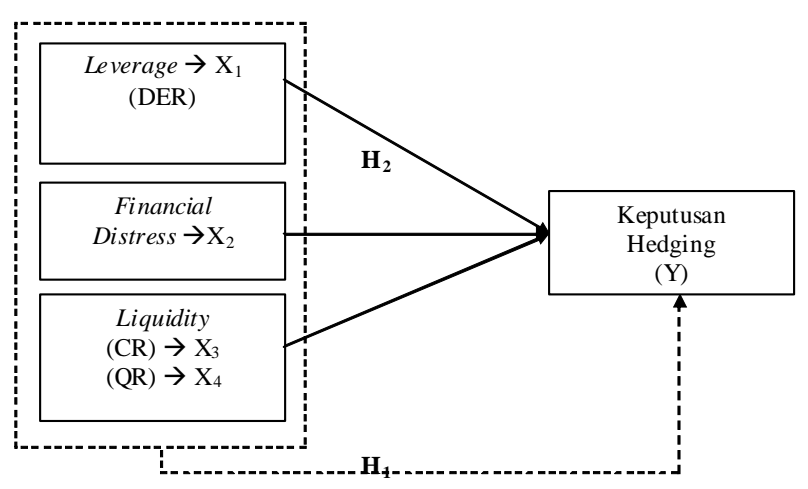

\section{Keterangan:}

$\longrightarrow$ : Berpengaruh secara parsial

$---\rightarrow$ : Berpengaruh secara simultan

\section{HIPOTESIS}

$\mathrm{H}_{1} \quad$ = Diduga terdapat pengaruh signifikan secara simultan variabel (DER, FD, CR dan $\mathrm{QR}$ ) terhadap keputusan hedging.

$\mathrm{H}_{2.1}$ = Debt to equity ratio berpengaruh positif terhadap keputusan hedging.

$\mathrm{H}_{2.2}=$ Financial distress berpengaruh negatif terhadap aktivitas hedging.

$\mathrm{H}_{2.3}=$ Current Ratio berpengaruh positif terhadap keputusan kebijakan hedging.

$\mathrm{H}_{2.4}=$ Quick Ratio berpengaruh positif terhadap keputusan kebijakan hedging.

\section{METODE}

\section{Populasi dan Sampel}

Populasi yang digunakan dalam penelitian ini adalah semua perusahaan nonfinansial yang terdaftar di Jakarta Islamic Indeks pada periode 2011-2015.

Dalam menentukan sampel pada penelitian ini menggunakan metode purposive sampling yaitu penarikan sampel dengan pertimbangan tertentu (Suharyadi \& Purwanto, 2004:332). 
Tabel 1. Kriteria Pengambilan Sampel

\begin{tabular}{clc}
\hline No. & \multicolumn{1}{c}{ Kriteria Sampel } & Jumlah \\
\hline 1 & $\begin{array}{l}\text { Perusahaan yang daftar di bursa } \\
\text { JII periode 2011-2015 }\end{array}$ & 30 \\
2 & $\begin{array}{l}\text { Perusahaan yang tetap aktif } \\
\text { pada bursa JII selama periode }\end{array}$ & 12 \\
$2011-2015$ & $\begin{array}{l}\text { Perusahaan yang menyajikan } \\
\text { data dan laporan keuangan }\end{array}$ & 12 \\
4 & $\begin{array}{l}\text { Perusahaan yang melakukan } \\
\text { aktifitas hedging }\end{array}$ & 7 \\
\hline
\end{tabular}

Dalam penelitian ini dari 30 perusahaan yang terdaftar pada bursa Jakarta Islamic Index selama periode 2011-2015 terdapat 7 perusahaan yang memenuhi kriteria-kriteria sebagai sampel dalam penelitian ini. Adapun perusahaan-perusahaan yang menjadi sampel adalah sebagai berikut.

Tabel 2. Daftar Nama Sampel Perusahaan Nonfinancial Yang Terdaftar Di JII Periode 2011 Sampai 2015

\begin{tabular}{clc}
\hline No. & \multicolumn{1}{c}{ Nama Perusahaan } & Kode \\
\hline 1. & Astra Agro Lestari & AALI \\
2. & Alam Sutera Realty & ASRI \\
3. & Indo Tambangraya Megah & ITMG \\
4. & Lippo Karawaci & LPKR \\
5. & Semen Indonesia & SMGR \\
6. & Telekomunikasi Indonesia & TLKM \\
7. & Unilever Indonesia & UNVR \\
\hline
\end{tabular}

Data bersumber dari dokumentasi resmi yang telah dipublikasikan oleh Bursa Efek Indonesia (BEI) melalui websitenya dan langsung ke Pojok Bursa UIN Maliki Malang yaitu berupa data laporan keuangan tahunan (ICMD).

Definisi masing-masing variabel yang digunakan dalam penelitian ini adalah:

Hedging atau Lindung Nilai (Y). Variabel bebas dalam penelitian ini adalah perusahaan yang melakukan lindung nilai atau hedging. Di mana Menurut Faisal (2001:9). Hedging dapat dilakukan dengan menggunakan instrumen derivatif seperti, kontrak opsi, kontrak future, kontrak forward, dan swap.

Di dalam penelitian ini, melihat dari laporan keuangan tahunan yang sudah dikonsolidasi pada perusahaan sampel pada periode 2011-2015, jika perusahaan menggunakan instrumen derivatif sebagai langkah untuk melakukan aktivitas hedging, diberi angka 2 sebagai kategori bahwa perusahaan melakukan aktivitas hedging, dan diberi angka 1 apabila perusahaan tidak melakukan instrumen derivatif sebagai aktivitas hedging.
Debt to Equity Ratio (DER). Dept Equity Ratio merupakan rasio solvabilitas yang digunakan untuk mengukur kemampuan modal sendiri perusahaan untuk dijadikan jaminan semua hutang perusahaan. Dapat diformulasikan sebagai berikut: (Kasmir, 2010: 157)

Debt to Equity Ratio $(D E R)=\frac{\text { Total Hutang }}{\text { Total Ekuitas }}$

\section{Financial Distress}

Financial Distress adalah kondisi dimana perusahaan mengalami kesulitan keuangan dan terancam bangkrut. Adapun financial distress dapat di rumuskan sebagai berikut:

$$
\begin{array}{r}
Z=\frac{\text { Working Capital }}{\text { Total Assets }}+\frac{\text { Retairned Earning }}{\text { Total Assets }}+\frac{\text { EAT }}{\text { Total Assets }} \\
+\frac{\text { Market Value of Equity }}{\text { Book value of Total Debt }}+\frac{\text { Total Revenue }}{\text { Total Assets }}
\end{array}
$$

\section{Liquidity}

Konsep likuiditas dapat diartikan sebagai kemampuan perusahaan dalam melunasi sejumlah utang jangka pendek, umumnya kurang dari satu tahun. Dimensi konsep likuiditas mencakup current ratio, quick ratio, cash ratio, dan net working capital to total assets rasio. Dimensi konsep likuiditas tersebut tercermin ukuran-ukuran kinerja manajemen ditinjau dari sejauh mana manajemen mampu mengelola modal kerja yang didanai dari utang lancar dan saldo kas perusahaan. Di mana rumus current ratio adalah sebagai berikut:

$$
\begin{aligned}
& \text { Curremt ratio }=\frac{\text { Aktiva Lancar }}{\text { Pasiva Lancar }} \\
& \text { Quick Ratio }=\frac{\text { Aktiva Lancar }- \text { Persediaan }}{\text { Pasiva Lancar }}
\end{aligned}
$$

\section{Metode Analisis Data}

Model analisis yang digunakan dalam penelitian ini adalah menggunakan model regresi linier berganda (Multiple Linear regression). Analisis ini diwali dengan uji Normalitas untuk mengetahui apakah residual model regresi yang diteliti terdistribusi normal atau tidak. Kemudian dilakukan Uji Asumsi Klasik yang meliputi Uji Multikolineritas, Uji Heteroskedastisitas, dan Autokorelasi. Selanjutnya adalah melakukan analisis regresi berganda untuk menunjukkan hubungan antara variabel bebas $(\mathrm{X})$ dengan variabel terikat (Y). 
$Y=a+b_{1} X_{1}+b_{2} X_{2}+b_{3} X_{3}+b_{4} X_{4}+\varepsilon$

Keterangan:

$\mathrm{Y} \quad$ : Variabel dependen $\quad \mathrm{X}_{1}$ : DER (Debt to Equity Ratio)

$\mathrm{X}_{2} \quad$ : FD (Financial Distress) $\quad \mathrm{X}_{3} \quad$ : CR (Current Ratio)

$\mathrm{X}_{4}$ : QR (Quick Ratio) a : Konstanta

$\mathrm{b}_{1} . . \mathrm{n}:$ Koefisien regresi $\quad \varepsilon \quad$ : error

\section{HASIL DAN PEMBAHASAN}

\section{Uji Normalitas}

Hasil pengujian dapat dilihat pada tabel 3 di bawah ini:

Tabel 3. Hasil Uji Normalitas Data

One-Sample Kolmogorov-Smirnov Test

\begin{tabular}{llr}
\hline & & $\begin{array}{c}\text { Unstandardized } \\
\text { Residual }\end{array}$ \\
\hline $\mathrm{N}$ & Mean & 60 \\
Normal Parameters & ${ }^{\mathrm{a}}$ & .0000000 \\
& Std. Deviation & .41244905 \\
Most Extreme Differences & Absolute & .162 \\
& Positive & .114 \\
& Negative & -.162 \\
Kolmogorov-Smirnov Z & & 1.252 \\
Asymp. Sig. (2-tailed) & & .087 \\
\hline
\end{tabular}

a. Test distribution is Normal.

Sumber: Data sekunder olahan SPSS versi 16

Berdasarkan tabel diatas memperlihatkan nilai Asymp. Sig (2-tailed) sebesar 0,087 >0,05, sehingga dalam penelitian ini residual model regresi terdistribusi secara normal atau asumsi normalitas terpenuhi.

\section{Uji Asumsi Klasik}

\section{Uji Autokorelasi}

Uji autokorelasi dalam penelitian ini diuji dengan menggunakan Runs Test, dengan hasil pada tabel 4 di bawah ini.

Tabel 4. Hasil Uji Autokorelasi Menggunakan Nilai Runs Test

\begin{tabular}{lr}
\hline & $\begin{array}{c}\text { Unstandardized } \\
\text { Residual }\end{array}$ \\
\hline Test Value $^{\mathrm{a}}$ & $.68964^{\mathrm{b}}$ \\
Cases $<$ Test Value & 59 \\
Cases $>=$ Test Value & 1 \\
Total Cases & 60 \\
Number of Runs & 3 \\
$\mathrm{Z}$ & .186 \\
A symp. Sig. (2-tailed) & .853 \\
\hline a. Median & \\
Sumber: data sekunder yang diolah &
\end{tabular}

Berdasarkan hasil analisis regresi 4 diperoleh nilai Asymp. Sig > taraf nyata $(\alpha)$ atau sebesar 5\% maka dapat dikatakan asumsi tidak terjadi autokorelasi terpenuhi.

\section{Uji Heterokedastisitas}

Uji asumsi ini bertujuan untuk mengetahui apakah dalam sebuah model regresi terjadi ketidaksamaan variasi dari residual antara suatu pengamatan dengan pengamatan yang lain. Dalam penelitian ini, asumsi Heteroskedastisitas diuji dengan menggunakan uji koefisien korelasi Rank Spearman.

\section{Tabel 5. Hasil Uji Heteroskedastisitas Menggunakan} Rank Sperman

\section{Correlations}

\begin{tabular}{|c|c|c|c|}
\hline & & & ABS_RES \\
\hline \multirow{12}{*}{$\begin{array}{l}\text { Spearman's } \\
\text { rho }\end{array}$} & \multirow[t]{3}{*}{ DER } & Correlation Coefficient & $-.344^{* *}$ \\
\hline & & Sig. (2-tailed) & .057 \\
\hline & & $\mathrm{N}$ & 60 \\
\hline & \multirow[t]{3}{*}{ FD } & Correlation Coefficient & .007 \\
\hline & & Sig. (2-tailed) & .956 \\
\hline & & $\mathrm{N}$ & 60 \\
\hline & \multirow[t]{3}{*}{$\mathrm{CR}$} & Correlation Coefficient & .167 \\
\hline & & Sig. (2-tailed) & .201 \\
\hline & & $\mathrm{N}$ & 60 \\
\hline & \multirow[t]{3}{*}{ QR } & Correlation Coefficient & .183 \\
\hline & & Sig. (2-tailed) & .163 \\
\hline & & $\mathrm{N}$ & 60 \\
\hline
\end{tabular}

**. Correlation is significant at the 0.01 level (2-tailed).

Sumber: Data sekunder olahan SPSS versi 16

Dari tabel correlation diatas menunjukkan bahwa variabel yang diuji menunjukkan nilai Sig. diatas 0,05 , sehingga asumsi tidak terjadinya Heterokedastisitas terpenuhi.

\section{Uji Multikolinieritas}

Uji Multikolinieritas diuji dengan tolerance VIF.

Tabel 6. Hasil Uji Multikolonieritas Menggunakan Coefficients $^{a}$

\section{Nilai VIF dan Tollerance}

\begin{tabular}{llcc}
\hline \multirow{2}{*}{ Model } & \multicolumn{2}{c}{ Collinearity Statistics } \\
\cline { 2 - 3 } & Tolerance & VIF \\
\hline 1 & (Constant) & & \\
& DER & .731 & 1.369 \\
& FD & .953 & 1.049 \\
CR & .252 & 3.961 \\
& QR & .212 & 4.728 \\
\hline
\end{tabular}

a. Dependent Variable: YSumber: Data sekunder olahan SPSS versi 16 
Dari tabel 6 di atas menunjukkan hasil perhitungan SPSS yang menunjukkan seluruh nilai VIF kurang dari 10 dan nilai tolerance diatas 0,1 , dengan demikian dapat disimpulkan bahwa asumsi tidak terjadi multikolinieritas dalam penelitian ini telah terpenuhi.

\section{Analisis Regresi Berganda}

Hasil regresi digunakan untuk membangun suatu persamaan yang menghubungkan antara variabel tidak bebas (Y) dengan variabel bebas (X). Hasil pengujian dengan SPSS diperoleh hasil analisis regresi berganda sebagai berikut:

Tabel 7. Hasil Perhitungan Regresi Linier Berganda Coefficients $^{a}$
Dari hasil analisis regresi dapat diketahui bahwa secara bersama-sama variabel independen memiliki pengaruh yang signifikan terhadap variabel dependen. Hal ini dibuktikan dari nilai $\mathrm{F}_{\text {hitung }}$ sebesar 6,229 dengan nilai probabilitas sebesar 0,00 . Karena probabilitas lebih kecil dari 0,05 atau 5\% maka model regresi dapat digunakan untuk memprediksi keputusan melakukan aktivitas hedging atau dapat dikatakan bahwa variabel DER, Financial Distress, CR dan QR secara bersama-sama berpengaruh signifikan terhadap aktivitas perusahaan dalam melakukan keputusan hedging.

\begin{tabular}{|c|c|c|c|c|c|c|}
\hline & & $\begin{array}{r}\text { Unstandard } \\
\text { Coefficier }\end{array}$ & ized & $\begin{array}{c}\text { Standardized } \\
\text { Coefficients }\end{array}$ & & \\
\hline \multicolumn{2}{|c|}{ Model } & B & Std. Error & Beta & $\mathrm{t}$ & Sig. \\
\hline \multirow[t]{5}{*}{1} & (Constant) & 1.752 & .178 & & 9.860 & .000 \\
\hline & DER & .144 & .118 & .159 & 1.219 & .228 \\
\hline & $\mathrm{FD}$ & -.004 & .010 & -.042 & -.370 & .713 \\
\hline & $\mathrm{CR}$ & .158 & .073 & .484 & 2.173 & .034 \\
\hline & $\mathrm{QR}$ & -.397 & .123 & -.784 & -3.224 & .002 \\
\hline
\end{tabular}

a. Dependent Variable: $Y$

Sumber: Hasil output SPSS 16

Berdasarkan tabel 7 di atas dapat disusun persamaan regresi berganda yaitu:

$\mathrm{Y}=1,752+0,144$ DER - 0,004 FD + 0,158CR $0,0397 \mathrm{QR}+\mathrm{e}$

\section{Pengujian Hipotesis}

\section{Uji F}

Uji statistik F pada dasarnya menunjukkan apakah semua variabel independen yang dimasukkan dalam model mempunyai pengaruh secara bersama-sama terhadap variabel dependennya. Hasil perhitungan uji F dapat dilihat pada tabel di bawah ini:

\section{Uji t}

Dari data yang diperoleh kemudian dianalisis dengan metode regresi dan dihitung dengan menggunakan software SPSS. Berdasarkan output SPSS tersebut secara parsial pengaruh dari ke empat variabel independen yaitu DER, FD, CR dan QR ditunjukkan pada tabel 8 .

Dari tabel 8 dapat diuraikan hasil perhitungan dari masing-masing variabel adalah sebagai berikut:

\section{Variabel DER}

Berdasarkan perhitungan diperoleh nilai $\mathrm{t}_{\text {hitung }}$ sebesar 0,1219 dan nilai signifikansi sebesar 0,228

Tabel 7. Hasil Uji F

ANOVA $^{\text {b }}$

\begin{tabular}{llrrrrr}
\hline Model & & Sum of Squares & df & Mean Square & \multicolumn{1}{c}{ F } & Sig. \\
\hline \multirow{2}{*}{1} & Regression & 4.547 & 4 & 1.137 & 6.229 & $.000^{\mathrm{a}}$ \\
& Residual & 10.037 & 55 & .182 & & \\
\hline & Total & 14.583 & 59 & & & \\
\hline
\end{tabular}

a. Predictors: (Constant), QR, FD, DER, CR

b. Dependent Variable: $Y$ 
Tabel 8. Hasil Uji t

\begin{tabular}{cccc}
\hline Variabel & $\mathbf{t}_{\text {hitung }}$ & Sig & Hasil \\
\hline DER & 0,1219 & 0,228 & Tidak Signifikan \\
FD & $-0,370$ & 0,713 & Tidak Signifikan \\
CR & 0,2173 & 0,034 & Signifikan \\
QR & $-0,3224$ & 0,002 & Signifikan \\
\hline
\end{tabular}

Sumber: Data sekunder yang diolah, 2016

yang berarti $\alpha>0,05$ maka $\mathrm{H}_{0}$ diterima, koefisien regresi tidak signifikan. Hal ini berarti secara persial variabel DER tidak berpengaruh signifikan terhadap keputusan perusahaan dalam melakukan aktivitas hedging.

\section{Variabel Financial Distress}

Berdasarkan perhitungan diperoleh nilai $\mathrm{t}_{\text {hitung }}$ sebesar $-0,370$ dan nilai signifikansi sebesar 0,713 yang berarti $\alpha>0,05$ maka $\mathrm{H}_{0}$ diterima, koefisien regresi tidak signifikan. Hal ini berarti secara parsial variabel FD tidak berpengaruh signifikan terhadap keputusan hedging.

\section{Variabel CR}

Berdasarkan perhitungan diperoleh $\mathrm{t}_{\text {hitung }}$ sebesar 0,2173 dan nilai signifikansi sebesar 0,034 yang berarti $\alpha<0,05$ maka $\mathrm{H}_{\mathrm{a}}$ diterima, koefisien regresi signifikan. Hal ini berarti secara parsial variabel CR berpengaruh signifikan terhadap keputusan melakukan aktivitas hedging.

\section{Variabel QR}

Berdasarkan perhitungan diperoleh $\mathrm{t}_{\text {hitung }}$ sebesar $-0,3224$ dan nilai signifikansi sebesar 0,002 yang berarti $\alpha<0,05$ maka $\mathrm{H}_{\mathrm{a}}$ diterima, koefisien regresi signifikan. Hal ini berarti secara parsial variabel QR berpengaruh signifikan terhadap keputusan hedging.

\section{Uji Variabel Dominan}

Menurut Ghozali (2005:88) uji dominan digunakan untuk mengetahui variabel mana yang paling dominan berpengaruh terhadap variabel terikat. Untuk menentukan variabel bebas yang paling menentukan (dominan) dalam mempengaruhi nilai variabel terikat dalam suatu model regresi linier, maka digunakan koefisien Beta (Beta Coefficient). Koefisien tersebut disebut Standaedized Coeffocoent. Tabel 9 dapat dilihat hasil dari nilai Standaedized Coefficient, Sebagai berikut:
Tabel 9. Standardized Coefficients

Coefficients $^{a}$

\begin{tabular}{llr}
\hline & & $\begin{array}{c}\text { Standardized } \\
\text { Coefficients }\end{array}$ \\
\hline Model & & \multicolumn{2}{c}{ Beta } \\
\hline 1 & (Constant) & \\
& DER & .159 \\
& FD & -.042 \\
& CR & .484 \\
& QR & -.784 \\
\hline
\end{tabular}

a. Dependent Variable: $Y$

Sumber: Data sekunder diolah

Dengan menggunakan bantuan software SPSS, didapatkan statistik uji dominan. Variabel yang paling dominan ditunjukkan oleh variabel Current Ratio (CR) dengan nilai standardized coefficients sebesar 0,484 . Nilai tersebut lebih besar dari pada variabel lain yang signifikan, yaitu DER. Pertimbangan perusahaan ketika menganalisis akan melakukan aktivitas hedging hendaknya melihat variabel yang paling dominan atau variabel yang paling besar mempengaruhi keputusan hedging, yaitu variabel variabel current ratio yang mempunyai pengaruh sebesar 0,484 terhadap keputusan hedging. Interpetasi pada variabel variabel current ratio adalah jika hasil current ratio semakin besar berarti perusahaan tersebut harus melakukan aktivitas hedging.

\section{KESIMPULAN DAN SARAN}

\section{Kesimpulan}

Berdasarkan hasil analisis data dari penelitian yang telah dilakukan tentang pengaruh Debt to Equity Ratio (DER), Financial Distress (FD) Current Ratio (CR), dan Quick Ratio (QR), secara parsial dan bersama-sama terhadap keputusan hedging pada perusahaan yang terdaftar pada indeks Jakarta Islamic Indeks maka dapat disimpulkan sebagai berikut: (1) Secara simultan, kemampuan variabel 
bebas Debt to Equity Ratio (DER), Financial Distress (FD) Current Ratio (CR), dan Quick Ratio (QR) berpengaruh secara signifikan terhadap keputusan untuk melakukan aktivitas hedging; (2) Secara Parsial, current ratio sebagai proksi dari liquidity memiliki pengaruh yang positif dan signifikan terhadap keputusan perusahaan melakukan hedging pada perusahaan yang terdaftar pada indeks JII. Ini menunjukkan bahwa semakin tinggi nilai current ratio maka semakin tinggi pula keputusan untuk melakukan hedging, karena tingginya risiko dalam pemenuhan kewajiban jangka pendek. Kemudian untuk variabel Quick ratio $(Q R)$ memiliki pengaruh yang negatif dan signifikan terhadap keputusan hedging, hal ini berarti bahwa jika nilai dari variabel QR kearah negatif, maka keputusan melakukan hedging akan semakin besar, karena jika QR rendah maka perusahaan tidak mampu membayar hutang jangka pendek. Variabel Debt equity ratio (DER) sebagai proksi dari leverage mempunyai pengaruh yang positif akan tetapi tidak signifikan terhadap keputusan perusahaan dalam melakukan aktivitas hedging pada perusahaan yang terdaftar di JII. Sedangkan variabel yang mempunyai pengaruh negatif dan tidak signifikan yaitu Financial Distress (FD) Financial Distress mempunyai pengaruh yang negatif terhadap keputusan hedging pada perusahaan yang terdaftar pada indeks JII, ketika nilai dari Altman Z-Score pada perusahaan akan terdorong untuk melakukan keputusan hedging.

\section{Saran}

Bagi perusahan, diharapkan untuk memperhatikan informasi internal perusahaan yakni Debt to Equity Ratio (DER), Financial Distress (FD) Current Ratio (CR), dan Quick Ratio (QR) yang merupakan variabel untuk menghitung kemampuan perusahaan dalam memenuhi hutang-hutangnya, sehingga dengan menggunakan ketiga variabel ini dapat dilihat seberapa likuid suatu perusahaan. Hal ini perlu dilakukan dikarenakan mencegah perusahaan mendapatkan risiko eksposur valuta asing yang seharusnya dapat dialihkan oleh penggunaan instrumen derivatif sebagai sarana hedging, dan mencegah perusahaan untuk mengeluarkan biaya derivatif dengan tidak memberikan manfaat yang diharapkan.

Bagi Investor, hendaknya investor yang akan melakukan investasi diberbagai perusahaan yang terdaftar pada indeks Jakarta Islamic Indeks dapat memilih perusahaan yang sudah melakukan hedging, hal ini dikarenakan ada jaminan bahwa perusahaan akan lebih aman apabila terjadi risiko dimasa mendatang. Bagi penelitian selanjutnya hendaknya menambah variabel internal perusahaan lainnya meliputi profitabilitasnya, arus kas dan membandingkan pada perusahaan yang ada di bursa luar negeri, sehingga model penelitian yang dihasilkan lebih kompleks.

\section{DAFTAR RUJUKAN}

Atmaja, Lukas Setia. 2008. Teori dan Praktik Manajemen Keuangan. Yogyakarta: ANDI.

Brigham, Eugene, F., \& Houston, Joel, F. 2007. Essential of Finance Management, Second Edition, Cengage Learning Asia Pte Ltd. Yulianto, Ali Akbar (penerjemah, 2012). Dasar-Dasar Manajemen Keuangan. Edisi Dua. Jakarta: Salemba Empat.

Faisal, M. 2001. Manajemen Keuangan Internasional. Edisi Pertama. Jakarta: Salemba Empat.

Fitriasari, Fika. 2011. Value Drivers terhadap Nilai Pemegang Saham Perusahaan yang Hedging di Derivatif Valuta Asing. Jurnal Manajemen Bisnis, 1 (1): h: 89-102.

Indrawan, Fiskara, dkk. 2012. Pengaruh Pelindungan Nilai Tukar Terhadap utang Luar Negeri dan Kinerja Perusahaan: Bukti Dari Data Panel. Working Paper. WP/14/2012. Bank Indonesia (http://bi.go.id).

Hanafi, Mamduh, M. 2006. Manajemen Risiko. Yogyakarta: Sekolah Tinggi Ilmu Manajemen YKPN.

Muqorobin, Agus, Nasir, Moech. 2009. Penerapan Rasio Keuangan Sebagai Alat Ukur Kinerja Perusahaan. BENEFIT Jurnal Manajemen dan Bisnis. 13 (1). 113.

Kasmir. 2010. Dasar-dasar Perbankan. Jakarta: Rajawali Pers.

Paranita, Ekayana Sangkasari. 2011. Kebijakan Hedging dengan Derivatif valuta Asing Pada Perusahaan Publik Di Indonesia. Seminar Nasional Ilmu Terapan UNIMUS. 228-237.

Putro, Septama Hardanto, Chabachib, M. 2012. Analisis Faktor Yang Mempengaruhi Penggunaan Instrumen Derivatif sebagai Pengambilan Keputusan Hedging (Studi Kasus pada Perusahaan Automotive and Alliend Products yang Terdaftar di BEI Periode 20062010). Ejournal sl Diponegoro, 1 (1). 1-11.

Santoso, Singgih, 2011. Buku Latihan SPSS statistik parametik, Jakarta: PT Elex Media Komputindo.

Subramanyam, K.R., \& Wild, John, J. 2013. Analisis Laporan Keuangan. Jakarta: Salemba Empat.

Suharyadi \& Purwanto. 2004. Statistik: untuk Ekonomi \& Keuangan Modern. Jakarta: Salemba Empat.

Sunaryo, T. 2007. Manajemen Risiko Finansial. Jakarta: Salemba Empat.

Jiwandhana, R.M., Satwika, Putra, Triaryati, Nyoman. 2016. Pengaruh Leverage dan Profitabilitas Terhadap 
Al Fatimia, Muhammad Sulhan

Keputusan Hedging Perusahaan Manufaktur Indonesia. E-Jurnal Manajemen Unud, 2 (1). 31-58. http://bisniskeuangan.kompas.com

http://bps.go.id

http://www.bi.go.id 